原著

\title{
小児穿孔性虫垂炎における化学療法の臨床的及び細菌学的検討
}

千葉大学小児外科

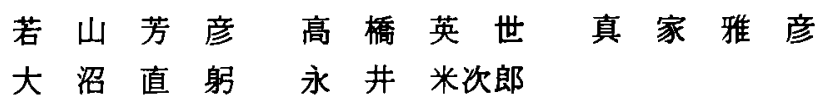

国立習志野病院小児外科

飯 田 秀 治

\section{CLINICAL AND BACTERIOLOGICAL STUDY OF CHEMOTHERAPY IN PERFORATED APPENDICITIS IN CHILDREN}

Yoshihiko WAKAYAMA, Hideyo TAKAHASHI, Masahiko MAIE

Naomi OHNUMA and Yonejirō NAGAI

The Department of Pedidatric Surgery, Chiba University Hospital Hideji IIDA

The Department of Pediatric Surgery, Narashino National Hospital

小児虫垂炎は，比較的頻度の高い疾患の一つで，全身管理の向上により死亡症例は極 めて稀となってきたが, 術後合併症, 特に術後創感染, 遺残膿瘍は依然として高頻度に みられている。我々は，小児穿孔性虫垂资に高頻度で検出される嫌気性菌の Bacteroides fragilis の特異的な抗生剂感受性パターンに注目し，1978年以降 Bact. fragilis に対する 抗生剂を投与し, 術後感染症の発生頻度を激減させ得た。

対象は，1968年より1983年の16年間に千葉大学で経験した小児虫垂炎182例中，穿孔性 虫垂炎88例である。

手術時腹腔内検出菌では，大腸菌 (82\%), 緑膿菌 (18\%) 等好気性グラム陰性楿菌と 嫌気性グラム陰性桿菌の Bact. fragilis (68\%) が大多数を占めた。㭪後感染巣検出菌で ๖, Bact. fragilis (59\%), 大腸菌（53\%), 緑膿菌（18\%）とほぼ同様の結果であった。 年代別㭪後感染症発生頻度では，费気性菌に対し有効な抗生剂の投与されなかった期間 の発生率が極めて高く，創感染33例中16例49\%，遺残膿煌 7 例21\%であった. 1978年以 降，嫌気性菌の Bact. fragilis に対して Lincomycin, Metronidazole*を投与し，創感染 40 例中 8 例 $20 \%$, 遺残膿汮 1 例 $3 \%$ ，と約 $1 / 2 \sim 1 / 7$ に减少させ得た。

小児穿孔性虫垂炎の化学療法は, 好気性グラム陰性桿菌に対する第二世代セフェム系 抗生剤, アミ /配榶体系抗生剂と, 嫌気性菌の Bact. fragilis に対する Metronidazole, Clindamycinの併用投与が適当であり，特に，Bact. fragilisに対する抗生剂投与の重要 性を強調したい。

索引用語：小児穿孔性虫垂炎, 化学療法, 嫌気性菌, Metronidazole

はじめに

小児虫垂炎は，日常診療上よく遭遇する頻度の多い 矮患の一つである.しかし, 診断・治療上多くの問題

・現在漛気性菌は保険の適応菌種にはなっていない
点を残しており，小児期特に学童前期から幼児期では， 患児の訴える不正確で診断に苦虑する場合す多く，末 た病繁の進行は早く容易に穿孔をおこす12). 更に, 全 身及び局所感染防御能力の低い小児では，汎発性腹獏 炎の頻度が高く，全身管理の向上により死亡率は激娍 
したが，術後合併症は依然として高頻度にみられてい ろ. 術後合併症の中では, 感染性合併症, 特に創感染, 遗残膿場の頻度が圧倒的に高く2)3)，厳重な創管理とと もに術後の化学療法が重要となる。我々は，本症に高 頻度で恰出される嫌気性菌の Bacteroides fragilis の 特異的な抗生剤感受性バーンに注目し()，1978年以 降 Bact. fragilisに対する抗生剤を投与することによ り訹後感染症の発生を激減させ得た。

今回，我々は小児穿孔性虫垂炎症例の細菌学的及び 臨床的検討の上に，小児穿孔性虫垂炎に拈ける化学療 法に検討を加光たので報告する。

\section{対象及U方法}

1968年より1983年の16年間に千葉大学小児外科，第 1 外科, 第 2 外科で経験した小児虫垂炎182例中穿孔性 虫垂炎88例を対象とした。

虫垂炎の分類は，手術時の肉眼所見にて行い，手術 時腹腔液の採取は開腹直後に行い,ケンキボーター に注入，好気性及び婙気性培養した。

\section{成 䋶}

1. 年数, 病型別分類

小児虫垂炎182例中 88 例 $48 \%$ が穿孔性であった。年齢 別頻度では，5歳以下は88例中 38 例 $43 \% ， 6 \sim 10$ 歳 37 例 $42 \% ， 11$ 14歳13例15\%である．各年龄別では， 5 歳以下 61 例 中 38 例 $62 \%, 6 \sim 10$ 葴74例 中 37 例 $50 \%$, $11 \sim 14$ 墄 47 例中 13 例 $28 \%$ で，年龄の低いるの程穿孔率 が高い(表 1).

\section{2. 術後合併症発生頻度}

カタル性32例，蜂蒚織炎性33例の術後には，合併应 は全く経験していない，壊㾝性29例中 1 例に遺残膿瘍 を認めた。穿孔性88例中29例 $33 \%$ に術後創感染，10例 $13 \%$ に遣残䝢場， 9 例 $10 \%$ に創哆開， 7 例 $8 \%$ に術後 イレゥスが発生し，創感染，遺残膿瘍の頻度が高い(表 2).

3. 手術時腹腔内検出菌

表 1 小坚虫垂炎一年龄・病型別分類一 （1968～1983千堡大学小児外科・1外・2 外）

\begin{tabular}{|c|c|c|c|}
\hline & ～-5歳 & $6-10$ 常 & 11～14藏 \\
\hline 力夕几性 & 4例( $7 \%)$ & 9例 (12\%) & 19例 (40\%) \\
\hline 蜂窝睵资性 & $10(16)$ & $14(19)$ & $9(19)$ \\
\hline 嫂 疾 性 & $9(15)$ & $14(19)$ & $6(13)$ \\
\hline 穿 孔 性 & $38(62)$ & $37(50)$ & $13(28)$ \\
\hline 合 計 & 61 & 74 & 47 \\
\hline
\end{tabular}

表 2 小児虫垂炎

一街後合併症一

（1968－1983 千葉大学小児外科・1外・2 外）

\begin{tabular}{|c|c|c|c|c|c|}
\hline & 症例数 & 創感染 & 遗残滕湿 & 㓣哆型 & イレウス \\
\hline カタル性 & 32 例 & 0 例 & O例 & 0 例 & 0 例 \\
\hline 蜂智輠炎性 & 33 & 0 & 0 & 0 & 0 \\
\hline 壊 㡺 性 & 29 & 0 & 1 & 0 & 0 \\
\hline 穿 孔 性 & 88 & $29(33 \%)$ & $10(11 \%)$ & $9(10 \%)$ & $7(8 \%)$ \\
\hline 合 計 & 182 & 29 & 11 & 9 & 7 \\
\hline
\end{tabular}

穿孔性虫垂炎88例中，手術時腹腔液の細菌検査の施 行された78例の検出菌を検討した。

好気性菌では, グラム陰性桿菌が圧倒的多数を占め, グラム陽性球菌の検出率は低い，大腸菌64株（82\%）, 緑膿菌14株 (18\%)，Klebsiella 11株（14\%）等で，ク ラム陰性桿菌は合計98株検出され，全検出株173株の $56.6 \%$ を占めた。

嫌気性菌では, クラム陰性桿菌の Bacteroides fragilis が多数を占め，53株(68\%)に検出されている。

大腸菌+Bact. fragilis の混合感染方半数以上を占 め, 複数の好気性グラム陰性桿菌+Bact. fragilis がこ れに次いだ(表 3 ).

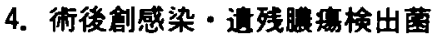

表3小児搴孔性虫垂炎 一手衍時腹腔内検出菌一

（应例数78例 $1968 － 1983$ 千集大学小坚外科・1外 - 2外)

\begin{tabular}{|c|c|c|}
\hline \multicolumn{3}{|l|}{ 好気性菌 } \\
\hline \multirow{4}{*}{$G(+)$} & Streptococcus viridans & 5 株 \\
\hline & Group D streptococcus & 5 \\
\hline & Staphylococcus aureus & 1 \\
\hline & $\mathrm{G}(+) \operatorname{cocci}$ & 4 \\
\hline \multirow{7}{*}{$\mathrm{G}(-)$} & E. coli & 64 \\
\hline & Pseudomonas aeruginosa & 14 \\
\hline & Klebsiella & 11 \\
\hline & Proteus & 4 \\
\hline & 腸内細菌類以菌 & 2 \\
\hline & Citrobacter & 2 \\
\hline & Group B Salmonella & 1 \\
\hline \multicolumn{3}{|l|}{ 嫌気性菌 } \\
\hline \multirow{3}{*}{$G(+)$} & Peptococcus & 3 \\
\hline & Propionibacterium & 2 \\
\hline & $\mathrm{G}(+)$ bacilli & 2 \\
\hline \multirow[t]{2}{*}{$\overline{G(-)}$} & Bacteroides fragilis & 53 \\
\hline & & 173株 \\
\hline
\end{tabular}


衰 4 小児穿孔性虫垂炎

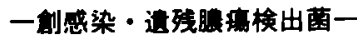

（症例数 17 例 $1968 \sim 1983$ 千葉大学小児外科・1外 $\cdot 2$ 外）

好気性菌

Staphylococcus aureus 16

G(t) Group A streptococcus

Group D streptococcus

E. coli

腸内綀菌類以菌

G(-) Pseudomonas aeruginosa

Klebsiella

Proteus

Group B Salmonella

\section{怒気性菌}

Bacteroides fragilis

10

31 株

術後創感染，遺残膿瘍をさたした40例中，細菌検査 の施行された17例の検出菌を検討した。

前述の手術時腹空内検出菌と全く同様の傾向を示 し，好気性グラム陰性桿菌と嫌気性グラム陰性桿菌の Bact. fragilis が多数を占めた. Bact. fragilis 10 株 (59\%)，大腸菌 9 株(53\%)，緑䐬菌 3 株 (18\%)と Bact. fragilis の検出頻度が高いことが注目される（表 4 ）.

\section{5. 主要細菌に対する抗生剂感受性}

前述の如く，小児穿孔性虫垂炎に拈ける起炎菌では， 好気性クラム陰性桿菌の大腸菌, 緑膿菌と嫌気性菌の Bact. fragilis が主たる細菌と言える。そこで，当院に おける上記細菌に対する抗生剤の感受性を検討した。
材料は，1982年の 1 年間に当院において検出された腹 部由来の膿で，MIC 2000を用いMICを測定した．当 院検査部では，以前はディスク法を用いて感受性を测 定しており，その経験により便宣的に（卅）（一)を 決め，(册）～（H）を感受性あり，(十) 〜 (一) を感 受性なし，とした。なお表中の数字は暴積\%を示して いる.

\section{（1）大胆药}

本菌に対し良好な感受性を示したのは, いわゆる第 II 〜III世代セフェム系抗生㓮とアミノ配糖体系抗生郕 である、とりわけ, Ceftizoxime (CZX) は0.1 $\mu \mathrm{g} / \mathrm{ml}$ で $85 \%$ の感受性を示し $4 \mu \mathrm{g} / \mathrm{ml}$ で100\%の感受性を有 した. Latamoxef (LMOX) metazole (CMZ) $8 \mu \mathrm{g} / \mathrm{ml}$ で $100 \%$, Ceftiam (CTM)

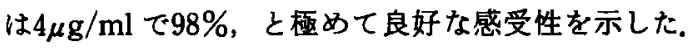
Gentamicin (GM) $84 \mu \mathrm{g} / \mathrm{ml}$ で91\%の感受性を示して いる(表 5 ).

（2）緑縢菌

本菌は，抗生剤に対する強い抵抗性を示し，大腸菌 に対する程の良好な感受性を示した薬剤は少ない。 Tobramycin (TOB), Amikacin (AMK) のアミ/配 糖体系抗生剂と抗緑膿菌剤の Cefsulodin (CFS) 70\%台の感受性を示したのみで，他の抗生剂の感受性 は低い．大腸菌に対して極めて高い感受性を示した第 三世代セフェム系抗生剂も，最良好と言われている Cefoperazone (CPZ) ですら56\%の感受性しか有して いない(表 6).

\section{(3) Bacteroides fragilis}

表 5 E. coli 55株

（1982.1～1982.12 千葉大模査部）

\begin{tabular}{|c|c|c|c|c|c|c|c|c|c|c|c|c|c|c|}
\hline $\mathrm{MIC}_{\mu \mathrm{g}} / \mathrm{ml}$ & 0.01 & 0.03 & 0.05 & 0.1 & 0.3 & 0.5 & 1 & 2 & 4 & 8 & 16 & 32 & 64 & \\
\hline 感受性 & \multicolumn{8}{|c|}{ (H) } & \multicolumn{2}{|c|}{ (H) } & \multicolumn{3}{|c|}{$(+)$} & $( \pm) \sim(-)$ \\
\hline $\mathrm{ABPC}$ & & & & & & & 6 & 26 & 43 & $56 \%$ & & & & \\
\hline PIPC & & & & & & 2 & 20 & 53 & 63 & & & $65 \%$ & & \\
\hline CEZ & & & & & 14 & 19 & 49 & 70 & 78 & 86 & & & $92 \%$ & \\
\hline CTM & & & 4 & 48 & 65 & 88 & 94 & & $98 \%$ & & & & & \\
\hline $\mathrm{CMZ}$ & & & & & 17 & 68 & 89 & 91 & 98 & $100 \%$ & & & & \\
\hline $\mathrm{CZX}$ & 25 & 30 & 73 & 85 & & 93 & 95 & 98 & $100 \%$ & & & & & \\
\hline LMOX & & & 3 & 24 & 26 & 97 & $100 \%$ & & & & & & & \\
\hline $\mathrm{CPZ}$ & & & 8 & 26 & 33 & 59 & 67 & 72 & 79 & $82 \%$ & & & & \\
\hline GM & & & & & 2 & 37 & 67 & 85 & $91 \%$ & & & & & \\
\hline $\mathrm{CP}$ & & & & & & & & 2 & 26 & 58 & $70 \%$ & & & \\
\hline
\end{tabular}


表 6 Pseudomonas aeruginosa46枺

\begin{tabular}{|c|c|c|c|c|c|c|c|c|c|c|c|c|}
\hline \multicolumn{13}{|c|}{ (1982.1 1982.12 千藮大検㚗部) } \\
\hline $\mathrm{MIC}_{\mu \mathrm{g}} / \mathrm{ml}$ & 0.1 & 0.3 & 0.5 & 1 & 2 & 4 & 8 & 16 & 32 & 64 & 128 & \\
\hline 感受性 & \multicolumn{5}{|c|}{ (H) } & \multicolumn{3}{|c|}{$(+H)$} & \multicolumn{3}{|c|}{$(+)$} & $( \pm)-(-)$ \\
\hline CBPC & & & & 2 & & & & & 17 & 52 & $59 \%$ & \\
\hline PIPC & & & 2 & & & 30 & 47 & 53 & 63 & 70 & $74 \%$ & \\
\hline CFS & & & & & 12 & 49 & 60 & 72 & 84 & $98 \%$ & & \\
\hline $\mathrm{CPZ}$ & & & 3 & & & 25 & 44 & 56 & 72 & 81 & $88 \%$ & \\
\hline TOB & & 12 & 19 & 37 & 65 & $72 \%$ & & & & & & \\
\hline AMK & & & & & 13 & 39 & 59 & $76 \%$ & & & & \\
\hline FOM & & & & 2 & 11 & 23 & 48 & 64 & 80 & & $84 \%$ & \\
\hline
\end{tabular}

表 7 Bacteroides fragilis 69 株

（1982.1 1982.12 千葉大㚗部）

\begin{tabular}{|c|c|c|c|c|c|c|c|c|c|c|c|c|c|}
\hline $\mathrm{MIC}_{\mu \mathrm{g}} / \mathrm{ml}$ & 0.03 & 0.05 & 0.1 & 0.3 & 0.5 & 1 & 2 & 4 & 8 & 16 & 32 & 64 & \\
\hline 感受性 & \multicolumn{6}{|c|}{ (m) } & \multicolumn{3}{|c|}{ (H) } & \multicolumn{3}{|c|}{$(+)$} & $( \pm) \sim(-)$ \\
\hline PC-G & & & & & & & 5 & 11 & $32 \%$ & & & & \\
\hline ABPC & & & 1 & & 3 & 6 & 9 & 10 & 19 & 46 & $57 \%$ & & \\
\hline PIPC & & & & & 1 & 4 & 16 & 38 & 57 & 67 & 74 & $77 \%$ & \\
\hline CMZ & & & & & & & 1 & 7 & 36 & 49 & 64 & $84 \%$ & \\
\hline LMOX & & & & & 3 & 44 & & 53 & 75 & 81 & & $88 \%$ & \\
\hline MINO & & 21 & 25 & 27 & & & 35 & 48 & $92 \%$ & & & & \\
\hline $\mathrm{CP}$ & & & & & & 2 & 17 & 76 & $100 \%$ & & & & \\
\hline LCM & & & & 3 & & 6 & 8 & 21 & 52 & $67 \%$ & & & \\
\hline CLDM & 2 & 11 & 15 & 27 & 53 & 65 & $71 \%$ & & & & & & \\
\hline Metronidazole & & 1 & 3 & 7 & 50 & 90 & $100 \%$ & & & & & & \\
\hline
\end{tabular}

本菌の抗生剂感受性バターンは，極めて特異的であ る。すなわち，好気性菌に対し高い感受性を有するて ミノ配榶体系抗生剂の感受性が全くなく，外科領城で 繁用されるベニシリン系，七ファロスポリン系抗生剤 の感受性は低い，外科領域でははとんど使用されてい ない Metronidazole, Chloramphenicol (CP), Clindamycin (CLDM) などが良好な感受性を示すことで ある. 本菌に対して最す良好な感受性を示したのは, Metronidazole (Flagl ${ }^{\circledR}$ ) で $2 \mu \mathrm{g} / \mathrm{ml}$ で100\%の感受性 を示した. 次いで CP が8 $\mu \mathrm{g} / \mathrm{ml}$ で100\%, LMOX が16 $\mu \mathrm{g} / \mathrm{ml}$ で81\%, CLDM $か \mathbf{2} 2 \mu \mathrm{g} / \mathrm{ml}$ で71\%の感受性を示 した（表 7)。

\section{6. 年代別投与抗生都及ひ衡啳感染症発生頪度}

1968年から1983年を1968年〜1971年 I 期, 1972年 ～1977年 II 期，1978年～1983年III期に分け，年代別投
与抗生剂及び術後感染症発生頻度を検討した。

I 期はCP,ベニシリン系, セファロスボリン系, SM, $\mathrm{KM}$ 等のアミ/配糖体系抗生剤がほぼ同頻度て投与 されている.II期は，CP が㟟しい使用制限の為著明に 減少し、ペニシリン系，七フフロスポリン系抗生剤が 大多数を占めた，III期では，GM，TOB等のアミノ配

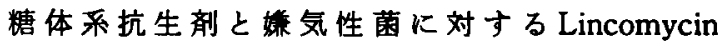
(LCM), Metronidazole が多数を占めた（表 8 ).

術後創感染は，I 期15例中 5 例 $33 \% ， I I$ 期33例中 16

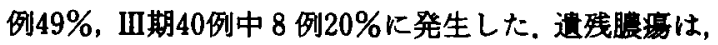
I 期15例中 2 例 $13 \%$ ，II期33例中 7 例 $21 \%$ ，III期40例 中 1 例 $3 \%$ 発生した。いずれるII期に極めて高制度 でみられっこの間に帮気性菌の Bact. fragilisに有効な 抗生剤は投与されていない。IIII期では，LCM， Metronidazole 等 Bact. fragilis に有効な抗生剂が投 
表 8 小児穿孔性虫垂炎一年代別使用抗生剂一（千葉 大学小児外科 $\cdot 1$ 外 $\cdot 2$ 外）

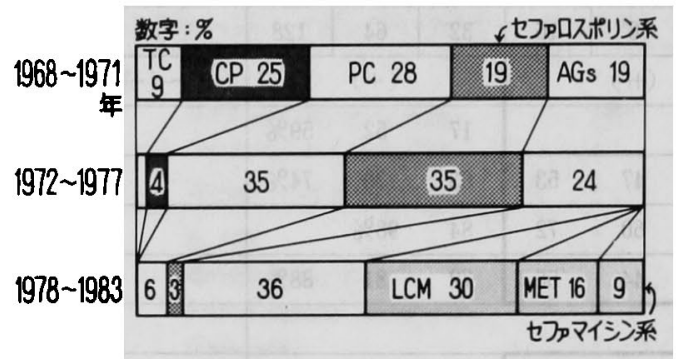

表 9 小児穿孔性虫垂炎

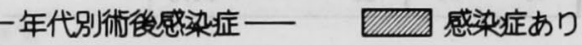
千菜大学小児外科・1外·2外

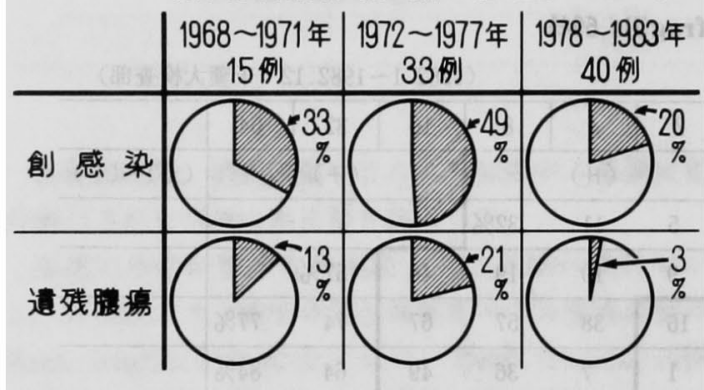

与され，創感染，遣残膿韵ともに激减している(表 9 ). 考案

穿孔性虫垂炎の術後合併症を防止すべく，Delayed wound closure ${ }^{5 / 6)}$, 手術創洗浄 ${ }^{7}$ 等多くの試みがなされ てきた。しかし，術後感染症の予防には，やはり化学 療法が中心なる。

化学療法を考える時 Host-parasite-drug relationshipを常に念頭におかなければならない。

Host：小児は成人に比べ感染防止機構が末熟であ り，局所感染から重篤な全身感染に移行する場合も多

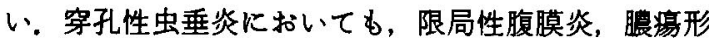
成の頻度は成人に比し低く，沉発性腹膜炎の型をとる ことが多い2．術後創感染，遺残膿瘍の頻度も高く，術 後感染巣より全身感染症を招来することも稀ではな い.

Parasite：穿孔性虫垂炎における起炎菌は，術後化 学療法の基礎として必ず検索しなくてはならない，好 気性菌のみならず嫌気性菌の培養・同定す必須で，開 腹後直ちに採取することが必要である，更に，起炎菌 の培盖・同定には日時を要する為，㭪後数日間は盲目 的な抗生刜投与にならざるを得ない。その為, 自施設 に批ける穿孔性虫垂炎の起炎菌の検出頻度を常に把㨋
しておく必要がある。

Drug：投与される抗生剤は，起炎菌に対する抗菌力 を有することか，ます絶対条件となる．更に，投与後 の副作用，耐性菌増加の問題，等を念頭においた抗生 鼡の選択が必要となる。

前述の如き原則をふま文，小児穿孔性虫垂焱におけ る術後化学療法を検討した。

まず起炎菌としては，今回の我々の検討では好気性 クラム陰性桿菌, 特に大腸菌、粶膿菌, Klebsiella と绕 気性グラム陰性桿菌の Bact. fragilis が圧倒的多数を 占めた，最近の報告でもほぼ同様の傾向を示し，㒖気 性菌に対する関心の增加，培養，同定技術の確立，简 素化により Bact. fragilisに言及した報告す增加して きた ${ }^{8)-10)}$. 虫垂内細菌叢は, 大腸内細菌讙とほぼ同し 細菌叢を形成しており，嫌気性菌は好気性菌の約 100 1,000倍存在しており，嫌気性菌が王倒的に莀位 である11.それ故, 虫垂穿孔によりひき抗こされる腹膜 炎に括いても嫌気性菌の関与は，想像に難くない，慻 気性菌の中では, 菌力, 抗生剤の感受性パターンから みて臨床的に問題となるのは、クラム陰性桿菌の Bact. fragilis である ${ }^{12)}$. 小児穿孔性虫垂炎における化 学療法の Taget となる起炎菌は，好気性クラム陰性桿 菌と嫌気性グラム陰性桿菌の Bacteroides fragilisで あると言えよう。

次に，前述の細菌に対する抗生剂の感受性をみると， 当院においては全ての好気性クラム陰性桿菌之嫌気性 菌の Bact. fragilis に対し単剤で cover し得る抗生用 はない，好気性ブラム陰性桿菌のなかであ大腸菌に対 しては多くの抗生剤が有奻であり，いわゆる第II世代 以降のセフェム系抗生㓮 (CMZ, CTM, CZX, LMOX etc) と, GM, TOB 等の $\mathrm{T}$ ，配糖体系抗生㓣の感受 性は高い。しかし，緑膿菌においては，ほとんどの抗 生剂の感受性は低く, CFS, TOB, AMK 等の抗緑腿菌 剂だけが良好な感受性を示した。好気性グラム陰性桿 菌全般に良好な感受性を示したのは，TOB，AMK等 のアミノ配糖体系抗生剂である。费気性菌のBact. fragilis は比較的特異な感受性パターンを示し，好気 性菌に対して良好な感受性を示したアミ／配糖体系抗 生用の感受性は全くなく，常用薬郕である ABPC, CEZ，等の感受性が低い。本菌に対して最す良好な感 受性を示したのは，抗トリコモナス郕である Metronidazole で, CP, CLDM, LMOX, PIPC 等が

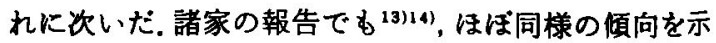
し，抗生㓮の感受性からは，好気性グラム陰性桿菌に 
は TOB 等のフミ，配糖体系抗生剂が適当であり，い わゆる第二世代以降のセフェム系抗生㓮が次に選択さ れる. Bact. fragilisに対しては, Metronidazole が最 も良く，CP，CLDM，LMOX, PIPC が次善の抗生剂と いえよう。

次に，抗生剂投与後の種々の副作用は，最少限に防 がなければならないまず，薬剤による人体への影響 からみると，アミノ配糖体系抗生剤は腎障害, 第䜣脳 神経障害が報告されている。いわゆる第二世代セフェ ム系抗生剂は，現在むでのところ重大な副作用は報告 されていない.第三世代セフェム系抗生剤は, Antabus 作用 ${ }^{15)}$, Pseudomembranous Enterocolitis, CP は再 生不良性貿血, CLDM \& Pseudomembranous Enterocolitisの発症が報告されている ${ }^{16)}$. Metronidazole は，抗トリコモナス用として長年にわたり投与されて いるか，さしたる副作用は報告されていない、17．以上， 抗生剤の人体に与える影暗からみると，好気性グラム 陰性桿菌に対しては第二世代せフェム系抗生郕か，嫌 気性菌に対しては Metronidazole が最適であると言 えよう。しかし，アミ，配糖体系抗生昘, 第三世代セ フェム系抗生剤，CLDM む，投与方法，投与間隔，投 与期間，等に配虑すれば，十分投与可能であると考え ている(1).

更に，投与後の副作用として耐性菌増加の問題を考 慮して扔かなければならない，耐性菌は抗生郕の投与 量とほほ比例して増加すると考えられており，無原則 な濫用は政につつしまねばならない。アミノ配糖体系 抗生剂，第三世代セフェム系抗生剂は，現在のところ いわば切り札的な菜剂であり，特に第三世代セフェム 系抗生浏は，発売間もないので First Choiceの投与は 避けた方が良いと考えている。しかし，穿孔性虫垂炎 は，外科感染症の中では比較的重篤な部類に属してお り，起炎菌が同定できるまでの短期間は，抗菌力の強 いBroad Spectrum の抗生剤の投与は許されると考 えている。第二世代セフェム系抗生剂, Metronidazole には，現在のところ耐性菌增加の問題は少なく，第一 選択としてょいと考㝋ている。

以上，起炎菌に対する抗菌力，副作用の面からみる と，好気性菌に対する第二世代セフェム系抗生剤， フ ミ，配糖体系抗生剂と嫌気性菌に対する Metronidazole, CLDM の併用投与が適当であると言えよう。

最後に, 術後感染症発生頻度よりみると，我々の成 䆊では，嫌気性菌に有効な抗生剂の投与されていない 期間の発生頻度が極めて高く，嫌気性菌に対し
Metronidazole, LCM（CLDM）を投与することによ り感染症の発生頻度を激減させ得た。穿孔性虫垂炎の 化学療法における抗嫌気性菌剤の投与は必須であるこ とを強調したい。

$$
\text { まとめ }
$$

小児穿孔性虫垂炎88例を対象に，術後化学療法の臨 床的及び細菌学的検討を行なった。

1. 手術時腹腔内検出菌では，大腸菌 (82\%) 緑膿菌 (18\%)等好気性グラム陰性桿菌と濑気性グラム陰性桿 菌の Bacteroides fragilis (68\%) の混合感染が大多数 を占めた。

2. 術後創感染検出菌では, Bact. fragilis (59\%) 大 腸菌（53\%）緑膿菌（18\%）と同様の傾向を示した.

3. 嫌気性菌の Bact. fragilisに対する Metronidazole, LCM (CLDM) を抗好気性菌娮と併用投与する ことにより術後感染症の発生頻度を著明に减少させ得 た.

4. 小児穿孔性虫垂炎の化学療法では，好気性クラム 陰性桿菌に対する第二世代セフェム系抗生剂, アミ, 配糖体系抗生剂之嫌気性菌の Bact. fragilis に対する Metronidazole, CLDMの併用投与が適当であると考 えている.

\section{文献}

1）角田昭夫：小児虫垂资の特殊性，外科診㞠，33： 297-301， 1979.

2）矢野博道, 小村順一：小児の急性虫垂资, 日本医事 新報, $2930: 23-29,1980$.

3) Stone, H.H., Sanders, S.L. and Martin Jr, J.D. : Perforated appendicitis in children. Surg., 69 : 673-679, 1971.

4）若山芳彦，高楀英世，横山宏他：小児虫垂炎一術 後感染症と嫌気性菌，日小外会誌，15：817-824， 1979.

5) Maddox, J.R., Johnson, W.W. and Sergeant, C. $\mathrm{K}$. : Appendectomies in a children's hospital. Arch. Surgery. 89 : 223-225, 1964.

6) Grosfeld, J.L. and Solit, R.W.: Prevention of wound infection in perforated appendicitis. Ann. Surg., 168: 891-895, 1968.

7) Gimore, O.J.A. and Martin, T.D.M. : Aetiology and prevention of wound infection in appendicectomy. Brit. J. Surg., 61 : 281-287, 1974.

8) Leigh, D.A.: Wound infections due to Bacteroides fragilis following intestinal surgery. Brit. 
J. Surg., 62 : 375-378, 1975.

9) Marchildon, M.B. and Dudgeon, D.L.: Perforated appendicitis. Ann. Surg., $185: 84-87,1977$.

10) Miholic, J., Riezinger, F. and Wurnig, P.: Metronidazole plus Cefazolin versus Cefazolin in gangrenous and perforated appendicitis in childhood-A prospective randomised trial. $Z$. kinderchir., 38 : 159-162, 1983.

11) Long, S.S. and Swenson, R.M.: Development of anaerobic fecal flora in healthy newborn infants. J. Pediat., 91 : 298-301, 1977.

12) Gorbach, S.L. and Bartlett, J.G.: Anaerobic infections. New Engl. J. Med., 290 : 1177-1184, 1974.

13）小酒井望, 岡田 淳, 小栗蕽子：各種病原細菌の抗 菌莱感受性の現状と将来, 日本臨床, 39 ：
121-134, 1981.

14) Nastro, L.J. and Finegold, S.M.: Bactericidal activity of five antimicrobial agents against Bacteroides fragilis. J. Inf. Dis., 126 : 104-107, 1972.

15) Reeves, D.S. and Davies, A.J. : Antabuse effect with Cephlosporin. Lancet, 540, 1980.

16) Bartlett, D.S., Chang, T.W., Gurwith, M., et al. : Antibiotic-associated pseudomembranous colitis due to toxin-producing clostridia. New Engl. J. Med., 298 : 531-534, 1978.

17) Bruce, T.A.: Dark urine related to Metronidazole therapy. J.A.M.A., $218:$ 1983, 1971.

18）若山方彦，饭田秀治，高橋英世他：新生児外科彻後 における Tobramycin 静注法の検討，小児外科。 12 : 979-984, 1980. 